TABLE 6

Program Budget

Summary of Actual Revenue Line Items for Fiscal Year 1995-96 and Projected Revenues for Fiscal Year 1996-97

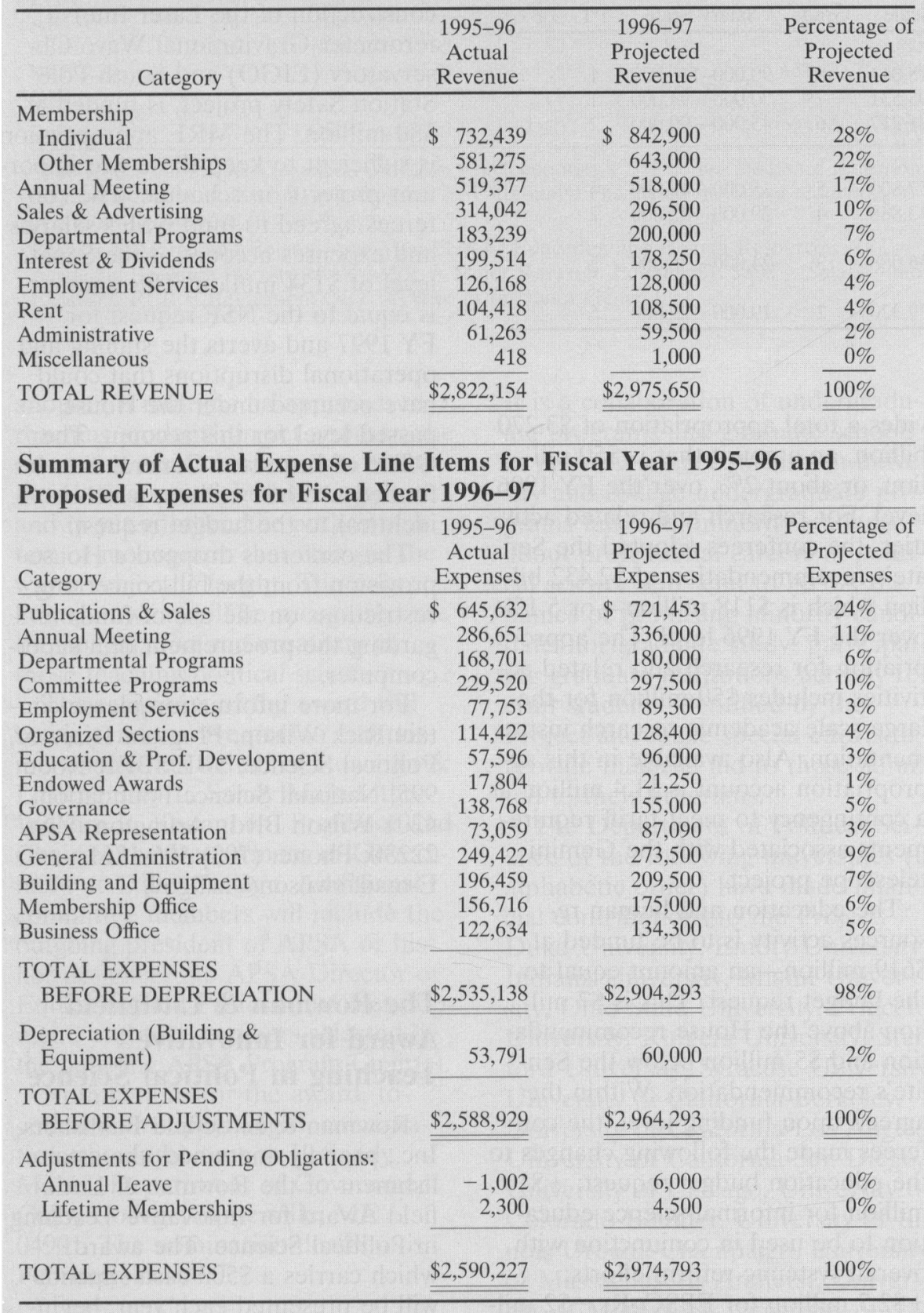

American college seniors to the world of graduate study and encourage their application to Ph.D. programs in political science. A representative from the Educational Testing Service assists students preparing for the Graduate Record Examination, and recruiters from graduate departments of political science are present to invite applications from the Bunche students.
This year marked the first Institute held at the University of Virginia, thanks to contributions from the University of Virginia and the National Science Foundation, a gift from the William S. Paley Foundation, and support from APSA. The Institute has been hosted in two other locations since its inception in 1986 - in Baton Rouge, Louisiana under the leadership of Jewell Pre- stage and Peter Zwick, and in Atlanta, Georgia under Lois Moreland and Jeanne Meadows.

\section{Jun Yin Joins APSA Staff}

Dr. Jun Yin has joined the APSA staff as a political staff associate as of August 19, 1996.

Dr. Yin grew up in Beijing, earned her BA and MA in international politics at Peking University in Beijing and then came to the United States for her doctoral work. She received her Ph.D. in 1995 from the University of New Orleans where she focused on comparative politics and environmental policy. Before coming to APSA, she worked at Xavier University of Louisiana's Center for Environmental Programs as a Program Manager of the Consortium for Environmental Risk Evaluation Project, funded by the U.S. Department of Energy. She has also taught at the University of New Orleans. She brings with her administrative experience, knowledge of grant administration, and considerable computer expertise. Among her duties at APSA will be to bring additional emphasis to international programs, a goal the Council endorsed at its April 20, 1996 meeting.

\section{APSA Archives Moved and Named for Walter E. Beach}

This August, APSA's archives were moved to Mount Vernon College's Eckles Library in Washington, DC after being housed at Georgetown University for over 20 years. APSA's Council subsequently approved naming the archives "The Walter E. Beach Archives of the American Political Science Association at Mount Vernon College." Beach is currently Publications Director at the Helen Dwight Reid Educational Foundation, and serves as Chair of Mount Vernon's Board of Trustees. He worked at APSA's National Headquarters between 1965 and 1980 as a Staff Associate and as Assistant Director of the Association, serving as Editor of $P S$ and Director of the Congressional Fellowship Program. Beach played a critical role in the Association's gov- 


\begin{tabular}{|c|c|c|c|c|c|c|}
\hline \multirow[b]{2}{*}{ APSA Position: } & \multirow{2}{*}{$\begin{array}{l}\text { Equivalent } \\
\text { Government } \\
\text { Grade }\end{array}$} & \multirow{2}{*}{$\begin{array}{c}1996 \\
\text { Federal } \\
\text { Salary Scale } \\
\end{array}$} & \multirow{2}{*}{$\begin{array}{c}\text { 1996-97 } \\
\text { APSA } \\
\text { Grade }\end{array}$} & \multirow{2}{*}{$\begin{array}{c}\text { 1996-97 } \\
\text { APSA } \\
\text { Salary Scale }\end{array}$} & \multicolumn{2}{|c|}{$\begin{array}{l}\text { Number of } \\
\text { Employees }\end{array}$} \\
\hline & & & & & FT & PT \\
\hline \multicolumn{7}{|l|}{ Political Scientists: } \\
\hline Executive Director & SES & $96,696-118,014$ & 8 & $90,000-115,000$ & 1 & \\
\hline Deputy Director & 15 & $73,486-95,531$ & 7 & $70,000-94,000$ & 1 & \\
\hline Program Directors & $13-14$ & $52,867-81,217$ & 6 & $45,000-90,000$ & 2 & 1 \\
\hline \multicolumn{7}{|l|}{ Non-Political Scientists: } \\
\hline Program Managers & $11-12$ & $37,094-57,800$ & 5 & $35,000-46,000$ & 4 & \\
\hline $\begin{array}{l}\text { Senior Administrative } \\
\text { Assistant }\end{array}$ & $9-10$ & $30,658-43,888$ & 4 & $29,000-42,000$ & 2 & \\
\hline $\begin{array}{l}\text { Staff Assistant; Building } \\
\text { Manager }\end{array}$ & $7-8$ & $25,061-36,088$ & 3 & $24,000-36,000$ & 5 & \\
\hline Admin. Asst., Receptionist & $4-6$ & $18,085-29,320$ & 2 & $19,000-29,000$ & 5 & \\
\hline
\end{tabular}

ernance, the organization of the Committees on the Status of Women, Blacks, and Chicanos in the Profession, and the development of the Association's international programs. Beach has also served as Secretary and Treasurer of the National Capitol Area Political Science Association and as an officer of the Southern Political Science Association.

APSA's archives encompass approximately 70 linear feet and 13 ranges of shelving. Extensive gleaning efforts have begun under the direction of Walter Beach who worked to find the archives' new home.

\section{NSF Funding Update}

Editor's Note: The following is reprinted from a September 25 posting to PSRT-L by Rick Wilson, Political Science Program Officer, NSF.

The fiscal 1997 Veterans AffairsHousing and Urban Development spending measure (containing the National Science Foundation budget line) of $\$ 84.7$ billion was approved by the House of Representatives on September 25 and forwarded to the White House for signature by the president. For the NSF, that pro- vides a total appropriation of $\$ 3.270$ lion, or about $2 \%$, over the FY 1996 level. For research and related activities, the conferees adopted the Senate's recommendation of $\$ 2.432$ billion which is $\$ 118$ million-or $5.1 \%$ over the FY 1996 level. The appropriation for research and related activities includes $\$ 50$ million for the large scale academic research instrumentation. Also available in this appropriation account is $\$ 1.4$ million as a contingency to meet tariff requirements associated with the Gemini telescope project.

The education and human resources activity is to be funded at $\$ 619$ million - an amount equal to the budget request. This is $\$ 7$ million above the House recommendation and $\$ 5$ million below the Senate's recommendation. Within the agreed upon funding level, the conferees made the following changes to the education budget request: $+\$ 10$ million for informal science education to be used in conjunction with overall systemic reform efforts; $+\$ 2.5$ million for EPSCoR; $-\$ 2$ million from graduate programs; $-\$ 5$ million from undergraduate programs; $-\$ 2.5$ million from precolbillion, an amount that is $\$ 50$ mil-

\section{Correction}

In a listing of standing APSA committees, the Committee on the Status of Lesbians and Gays was inadvertently not included. The chair of the committee is Harry Hirsch, University of California-San Diego. He may be reached via e-mail at hhirsch@weber.ucsd.edu.

lege curriculum development; and $-\$ 3$ million from research, evaluation, and communications.

The major research equipment (MRE) activity, which supports the construction of the Laser Interferometer Gravitational Wave Observatory (LIGO) and South Pole Station Safety project, is funded at $\$ 80$ million. The MRE appropriation is sufficient to keep these two important projects on schedule. The conferees agreed to fund NSF's salaries and expenses account at the Senate level of $\$ 134$ million. This amount is equal to the NSF request for FY 1997 and averts the staffing and operational disruptions that could have occurred under the House passed level for this account. The Office of Inspector General is to be funded at $\$ 4.69$ million, which is identical to the budget request.

The conferees dropped a House provision from the bill concerning restrictions on the use of funds regarding the procurement of a supercomputer.

For more information please contact Rick Wilson, Program Director, Political Science, SBE/SBER Room 995, National Science Foundation, 4201 Wilson Blvd., Arlington, VA 22230; Phone: (703) 306-1761; E-mail: rwilson@nsf.gov.

\section{The Rowman \& Littlefield Award for Innovative Teaching in Political Science}

Rowman \& Littlefield Publishers, Inc., proudly announces the establishment of the Rowman \& Littlefield Award for Innovative Teaching in Political Science. The award, which carries a $\$ 500$ cash stipend, will be presented each year, beginning in 1997, at the President-Elect's Reception at the American Political Science Association Annual Meeting.

The Innovative Teaching Award will recognize political scientists who develop effective new approaches to teaching in the discipline. The award seeks to honor a wide range of new directions in teaching, not a particular new direction. Thus, in one year a professor might be chosen because of an innovative course syllabus; in 